\title{
Use of Metabolism and Swimming Activity to Evaluate the Sublethal Toxicity of Surfactant (LAS-C12) on Mugil platanus
}

\section{Edison Barbieri*}

Instituto de Pesca; SAA SP; Av. Prof. Besnard s/n; C. P. 61; 11990-000; edisonbarbieri@yahoo.com.br; Cananéia SP - Brasil

\begin{abstract}
This study aimed to investigate the toxicological effects of the LAS-C12 on Mugil platanus (mullet). Fishes exposed to $1.0 \mathrm{mg} . \mathrm{L}^{-1}$ for 24, 48, 72, 96 and 120 hours presented significant increase in specific routine metabolism. At the concentration of $0.5 \mathrm{mgL}^{-1}$, the active metabolism presented a decreasing trend from $48 \mathrm{~h}$ of exposure on. However, only the consumption averages for $72 \mathrm{~h}$ were statistically different from the ones obtained for other periods of exposure. The lowest oxygen consumption in this concentration was observed for 24, 48 and 72 hours of exposure. Significant differences between the control and the concentration of $2.5 \mathrm{mgL}^{-1}$ were observed for the different periods of exposure. It was not possible to measure the consumption of oxygen for 96 and $120 \mathrm{~h}$, because the fishes got tired in less than one minute after they were placed in the respirometer. The time of swimming until exhausted for fish exposed to $2.5 \mathrm{mgL}^{-1}$ of LAS-C12 for $24 \mathrm{~h}$ was 8 minutes. Following 72 hours of exposure to this concentration, the fish got exhausted after 3 minutes.
\end{abstract}

Key words: LAS, swimming performance, oxygen consumption, metabolism, detergents

\section{INTRODUCTION}

The metabolic rate of an organism is an useful and sensitive indication of its daily consumption of energy. Therefore, in aerobic animals, the quantification of the rate of oxygen consumption will be directly associated to the amount of energy liberated from the oxidation of food substratum. Based on the amount of oxygen consumed by an animal for a certain period of time, it is possible to evaluate the energy spent during the same period to maintain its vital processes (Carvalho,1992).

The metabolism of a fish includes three welldifferentiated levels: standard metabolism, routine metabolism and active metabolism. The standard metabolism is the minimum energy required for the fish to survive, associated to rest and unfed state. The routine metabolism is the fraction of energy used by unfed fish with movement of spontaneous swimming, or routine activity. Routine metabolism is the mean rate oxygen consumption measured when precautions are taken against the fish being influenced by outside stimuli (Fry, 1971). The active metabolism represents the metabolic rate in the maximum level of activity. Brett and Groves (1979) demonstrated that fast swimming fish can increase their metabolism up to 10 times the standard metabolism, whereas fish of colder waters increase their metabolic rate by 2 or 3 times. In addition, the swimming performance

\footnotetext{
${ }^{*}$ Author for correspondence
} 
(Beamish, 1978) was recorded as the highest position-maintaining velocity plus the fraction of the time interval of the velocity in which they become exhausted (Reidy et al, 1995; Hammer and Schwarz, 1996; Hymel, et al., 2002; Wicks, et al., 2002), i.e., the physical capacity that facilitates fish to swim against a certain water direction during a certain period of time (Howard, 1975).

The active metabolism was referred by Fry (1971) as the maximum steady rate of oxygen consumption under continuous forced activity. This energy readiness for activity reflects the physiological state of the animal that is linked to the environmental conditions. In the context of environmental studies and biological monitoring, both energy readinesses for activity and routine metabolism are used (Scherech, 1990) and they constitute efficient tools to measure the toxicity of a chemical substance in an organism. Evaluation of fish metabolism was used, for example, to study toxicant effects caused by petroleum (Kloth and Wohlschiag, 1972), aromatic compositions (Lemaire et al., 1996), heavy metals (Hodson, 1988), detergents (Huang and Wang, 1994; Barbieri et al., 1998; 2002; Christiansen et al., 1998) and a variety of toxins (Boudou and Ribeyre, 1989).

Changes in swimming behavior as a result of exposure to sublethal pollutants can affect the fish capacity to feed, to flee from predators or even to reproduce (Little et al., 1985). Swimming behavior is frequently used as a parameter to evaluate toxicity in fish (Little and Finger, 1990). Therefore, swimming capacity and swimming activity are used to assess alterations in fish movement due to effects of pollutants. Swimming performance is a parameter related to the fish resistance to keep swimming in a water flow (Dodson and Mayfield, 1979) or to its physical capacity to keep on swimming against the flow (Howard, 1965, Hymel et al. 2002). Swimming performance also includes variables as frequency and duration of movements (Cleveland et al., 1986, Kolak, 1999), speed and distance traveled during the movement (Miller, 1980), frequency and angle of swimming to a flow (Rand, 1977), and position in the water column and type of swimming behavior (Kolak, 1999).

Swimming performance was used with success, for example, to study effects of organophosphat (Peterson, 1974), DDT (Besch et al., 1977), herbicides (Little et al., 1989), aluminum (Cleveland et al., 1986), copper (Walwood and
Beamish, 1978); detergents (Hofer et al., 1995; Barbieri, et al., 1998, 2000) and ammonia (Wicks et al., 2002). The use of the time of swimming until fatigue is one of the traditional protocols to study effects of environmental changes on the swimming capacity of fish (Rand, 1984, Barbieri et al., 2000).

The understanding of the possible effects of pollutants on the swimming capacity of aquatic organisms is very useful for environmental quality management. Those effects are hardly detected in a superficial analysis; however, they can drastically influence the survival and the success of species and communities. Exposure to sublethal doses, even if for a relatively short period of time, can affect the fish ability to feed, flee from predators, reproduce, etc. (Little et al., 1985). In addition to help understanding causal relationships between pollutants and physiologic processes, fish metabolism and swimming performance can indicate right away environmental deterioration, in a way that appropriate measures can be put in place to respond to environmental degradation (Barbieri et al., 1998). At the level of the individual, sublethal toxicant effects are manifested in several ways, but among the most sensitive indicators of pollution stress are behavioral alterations. In particular, feeding behavior has been investigated extensively because feeding impairment could have repercussions on an individual's survivorship, growth, reproductive capacity (Grippo and Heath, 2003), swimming performance (Barbieri et al., 2000) and metabolism (Barbieri et al., 2002). This is applied, mainly to estuaries where effects of human activities have been felt for centuries.

This study aimed to investigate the effect of the detergent (Linear Dodecy Benzene Sodium Sulfonate, LAS-C12) on routine and active metabolism as well as on swimming performance of Mugil platanus (mullet), a euryhaline and eurythermic fish, at the temperature of $20^{\circ} \mathrm{C}$ and salinity of $35 \%$. The study was undertaken using different concentrations of LAS-C12 $\left(0.0 \mathrm{mgL}^{-1}\right.$, $0.5 \mathrm{mgL}^{-1}, 1.0 \mathrm{mgL}^{-1}$ and $\left.2.5 \mathrm{mgL}^{-1}\right)$ at different exposure periods $(24,48,72,96$ and 120 h). To evaluate the effect of the LAS-C12 on the metabolism and on swimming performance, consumption of oxygen and time of swimming until exhausted were used as parameters, respectively. 


\section{MATERIALS AND METHODS}

The Linear Dodecyl Benzene Sodium Sulfonate (LAS-C12) was used in this study because: (a) it is widely used as the main active substance in detergents, and (b) there is a lack of studies on the toxicity of this element in marine and estuarine fish in Brazil (where this study was carried out). The reagent was diluted in distilled water in stock solution of $1 \mathrm{gL}^{-1}$. Such dilution was carried out just before undertaking the experiment in order to avoid degradation of the substance. Three different concentrations were tested, i.e., $0.5 \mathrm{mgL}^{-1} ; 1.0$ $\mathrm{mgL}^{-1}$ and $2.5 \mathrm{mgL}^{-1}$, as well as a control (water without LAS-C12), for the experiment on routine and active metabolism, and swimming capacity. The concentrations of $0.5 \mathrm{mgL}^{-1}, 1.0 \mathrm{mgL}^{-1}$ and
$2.5 \mathrm{mgL}^{-1}$ were also tested to evaluate the effect of exposure to a period up to 120 hours. LAS-C12 was introduced in a determined amount in the respirometer using a precision pipette, in order to obtain the required final concentration.

Dissolved oxygen and water viscosity are factors that affect oxygen consumption and swimming capacity of fish; therefore, they should be previously estimated when studying the effects of detergents. Therefore, experiments were conducted to verify effects of the LAS-C12 on oxygen's dissolution in the water and water viscosity. Oxygen concentration and $\mathrm{pH}$ of the test solutions were mensured, as well as ammonia values $\left(\mathrm{mML}^{-1}\right)$ as a function of the exposure time (in hours) at the different concentrations of LAS-C12.

Table 1 - Concentration of oxygen in the beginning and in the end (after one hour) of the experiments in different concentrations of LAS-C12 in the absence of consuming organisms. Each value is the average of five determinations; standard deviation in parentheses, temperature $20^{\circ} \mathrm{C}$ and salinity 35 .

\begin{tabular}{ccc}
\hline Concentration of LAS-C12 $\left(\mathbf{m g L}^{-\mathbf{1}}\right)$ & O2 beginning $\left(\mathbf{m l O}_{\mathbf{2}} \mathbf{L}^{-\mathbf{1}}\right)$ & $\mathbf{O 2} \mathbf{~ e n d ~}\left(\mathbf{m l O}_{\mathbf{2}} \mathbf{L}^{\mathbf{- 1}}\right)$ \\
0 & $6.230(0.023)$ & $6.232(0.067)$ \\
0.5 & $6.132(0.080)$ & $6.143(0.051)$ \\
1.0 & $6.232(0.058)$ & $6.259(0.029)$ \\
5.0 & $6.242(0.023)$ & $6.217(0.089)$ \\
\hline
\end{tabular}

This was done by filling up the respirometers with solutions of LAS-C12 in the same concentrations to be used in the experiments (i.e., $0.5 \mathrm{mgL}^{-1} ; 1.0$ $\mathrm{mgL}^{-1}$ and $\left.2.5 \mathrm{mgL}^{-1}\right)$. In the absence of fish, the respirometer was closed and the water was mixed for one hour. Five replicas were used for each concentration of LAS-C12 and for the control. Dissolved oxygen was measured in the beginning and in the end of each experiment (Table 1). $\mathrm{pH}$ ranged from 8.18 t0 8.20 at all test treatments. Ammonia measurements are shown in table 2.

Water viscosity in the three concentrations of LAS-C12 $\left(0.5 \mathrm{mgL}^{-1}, 1.0 \mathrm{mgL}^{-1}\right.$ and $\left.2.5 \mathrm{mgL}^{-1}\right)$ as well as in the control (water without surfactant) was measured using an Oswald's viscosimeter (Moore, 1976) to verify possible alterations in this factor as a result of the addition of the detergent. Five replicas of each experimental condition were used at the temperature of $20^{\circ} \mathrm{C}$ and salinity $35 \%$. There were not significant statistical differences in the viscosity between the concentrations of the LAS-C12. The average of the viscosity were: $1.046 \mathrm{~g} / \mathrm{m} / \mathrm{s}( \pm 0.006)$ for the control; $1.049 \mathrm{~g} / \mathrm{m} / \mathrm{s}$
$( \pm 0.008)$ for $0.5 \mathrm{mgL}^{-1} ; 1.054 \mathrm{~g} / \mathrm{m} / \mathrm{s}( \pm 0.009)$ for $1.0 \mathrm{mgL}^{-1} ; 1.038( \pm 0.005)$ for $2.5 \mathrm{mgL}^{-1}$.

\section{Effects of time of exposure to LAS-C12 on active metabolism, routine metabolism and time of swimming until exhausted}

The fishes were acclimatized at the salinity of $35 \%$ and temperature of $20^{\circ} \mathrm{C}$ and maintained in tanks of $200 \mathrm{~L}$ with constant aeration. Each tank contained five individuals. The water was renewed every two days to avoid any type of influence due to metabolites excreted by the animals. A total of 300 fish, divided in 60 groups of five animals, were used. Each group was submitted to one of the 20 possible combinations of the four concentrations of LAS-C12 and to the five exposure periods. The tested concentrations were of $0,0 \mathrm{mg} . \mathrm{L}^{-1}$ (control in pure water); $0.5 \mathrm{mgL}^{-1}$; $1.0 \mathrm{mgL}^{-1}$ and $2.5 \mathrm{mgL}^{-1}$. The periods of acclimation in LAS-C12 were of $24 ; 48 ; 72 ; 96$ and $120 \mathrm{~h}$. A stock solution of LAS-C12 was prepared in water distilled with concentration of $1 \mathrm{gL}^{-1}$, immediately before the use to avoid degradation of the substance. The necessary 
amount of the stock solution was introduced in the tanks, using a micropipette, in order to obtain the required final concentration. Half of the water of the tanks was changed every $24 \mathrm{~h}$ to avoid an increase of metabolites concentration, however, the concentration of the polluting agent was maintained by adding recently prepared increment of stock solution.

Table 2 - Ammonia values moles per $\mathrm{mL}\left(\mathrm{M} \mathrm{mL}^{-1}\right)$ as a function of the time of exposure (hours) in the different concentrations of LAS-C12 (ppm).

\begin{tabular}{c|c|c|c|c|c|c}
\hline Time (hours) & $\mathbf{0 . 1} \mathbf{~ m g L}^{-1}$ & $\mathbf{0 . 5} \mathbf{~ m g L}^{-\mathbf{1}}$ & $\mathbf{1 ~} \mathbf{~ g L}^{-\mathbf{1}}$ & $\mathbf{2 . 5} \mathbf{~ m L L}^{-\mathbf{1}}$ & $\mathbf{5} \mathbf{~ m g L}^{\mathbf{- 1}}$ & Control \\
\hline 24 & 0.112 & 0.115 & 0.112 & 0.120 & 0.111 & 0.116 \\
48 & 0.116 & 0.119 & 0.113 & 0.123 & - & 0.120 \\
72 & 0.119 & 0.125 & 0.120 & 0.125 & - & 0.125 \\
96 & 0.122 & 0.128 & 0.125 & 0.128 & - & 0.129 \\
120 & 0.125 & 0.130 & 0.131 & 0.132 & - & 0.130 \\
\hline
\end{tabular}

The fishes were not fed for the period of $48 \mathrm{~h}$ prior to undertaking the experiments. This was to determine the routine and active metabolism and the time of swimming until exhausted. It was attempted to select individuals of similar sizes and weights. The one used in the control were in average $4.2 \mathrm{~cm}( \pm 0.54)$ and $4.50 \mathrm{~g}( \pm 1.02)$; the ones submitted to concentrations of $0.5 \mathrm{mgL}^{-1}, 1.0$ $\mathrm{mgL}^{-1}$ and $2.5 \mathrm{mgL}^{-1}$ were in average $5.1 \mathrm{~cm}( \pm$ $1.02)$ and $4.80 \mathrm{~g}( \pm 1.08) ; 4.7 \mathrm{~cm}( \pm 1.03)$ and $5.26 \mathrm{~g}( \pm 0.64) ; 5.1 \mathrm{~cm}( \pm 0.74)$ and $5.2 \mathrm{~g}( \pm 0.96)$, respectively.

\section{Method to study the acute effect of LAS-C12 on the routine metabolism of $M$. platanus}

Before the beginning of the experiments, the animals were maintained in the respirometers with continuous water circulation for at least 90 minutes to attenuate the stress caused by handling. Then, the water supply was suspended and the respirometer was closed, so that the fish could consume the oxygen present in a known volume of water for a period of an hour. Only one fish was used in each respirometer. The respirometers were protected by an shield to isolate the animals from possible external disturbances in the laboratory. The difference between the concentrations of oxygen determined at the beginning and at the end of the confinement was used to calculate the consumption of the animal during that period. To minimize the effect of low oxygen concentration and the metabolites accumulation on the metabolism, the duration of the experiments was regulated so that the oxygen concentration at the end of experiments was larger than the $70 \%$ of its initial concentration. The dissolved oxygen was determined through the Winkler method.
To obtain the desired concentration of LAS-C12, the required volume of the stock solution $\left(1.0 \mathrm{gL}^{-}\right.$

$\left.{ }^{1}\right)$ was calculated for the volume in each respirometer and set with a micropipette at the end of the acclimation. As soon as LAS-C12 was added, the entry orifice of the respirometer was sealed.

Method to study the effect of LAS-C12 on the active metabolism and the time of swimming until exhausted

To quantify the effect of the acute exposure to LAS-C12 on the swimming activity and the active metabolism of the fish, swim tunnel was built and used in our laboratory, based on the descriptions of Brett (1964) and modified for individuals of small size. The swim tunnel consisted of a metabolic chamber placed inside a box with water, to help with temperature maintenance. The fishes were forced to swim against a current produced by a propeller attached to variable-seep electric motor. Each fish was allowed to adjust and orient itself in the chamber at a low water velocity. The speed of the current was measured through a "Venturi" meter flow type. A water sample was then taken and the outlets and inlets were closed. The water velocity was slowly increased within a short period until the fish could just maintain their position. At the end of the forced-swimming period, the water velocity was greatly reduced and a water sample was collected. To guide the flow and define the swimming space, flow laminators were installed in the two extremities of the metabolic chamber. The swim tunnel total volume was $1.2 \mathrm{~L}$.

Before the beginning of the experiments, the animals were maintained in the active respirometer (swim tunnel) with continuous water circulation 
during at least 90 minutes to attenuate the handling stress. Then, the water supply was suspended and the active respirometer was closed, so that the fish could consume the present oxygen in the known water volume for a period of an hour. The active respirometers were protected by a shield to isolate the animals from possible moves in the laboratory. The difference between the oxygen concentrations, determined at the beginning and at the end of the confinement, was used to calculate the consumption during the period. To minimize the effect of the low oxygen concentration and metabolites accumulation on the metabolism, the experiments duration was regulated so that the oxygen concentration by the end of experiments was larger than the $70 \%$ of its initial concentration. The dissolved oxygen was determined through the Winkler method.

After 90 minutes, the necessary amount of LASC12 stock solution was added to obtain the specified concentration. The speed was, then, slowly increased $\left(1 \mathrm{~cm} \cdot \mathrm{s}^{-1}\right)$ until reaching $15 \mathrm{~cm} \cdot \mathrm{s}^{-1}$ $( \pm 0.31)$, so that the fish were forced to swim in that speed until exhausted. Fish were considered exhausted when they could not maintain their speed in relation to the water flow, being dragged by the current to the exit extremity of the swim tunnel, staying in that position for more than $30 \mathrm{~s}$. The flow was monitored during the whole period of the experiment and the concentration of dissolved oxygen in the swim tunnel was determined at the beginning and end of the experiment, using the Winkler's method. The total oxygen consumption in each experiment was calculated by the difference between the initial and final concentration. To minimize the effect of the low oxygen concentration and metabolites accumulation on the metabolism, the experiments duration was regulated so that the oxygen concentration at the end of experiments was larger than the $70 \%$ of its initial concentration. The difference between the oxygen concentrations, determined at the beginning and at the end of the confinement, was used to calculate the consumption during the period. To obtain the LAS-C12 desired concentration, the necessary volume of the stock solution $\left(1.0 \mathrm{gL}^{-1}\right)$ was calculated for each respirometer's and set with a (micropipette) help at the end of the acclimation. As soon as LAS-C12 was added, the entry orifice was sealed. Immediately after each experiment, the total length and the wet weight of the tested animals were measured. No fish was used twice.
The processing and charting of the data were accomplished with aid of a spreadsheet. The average specific consumption of oxygen by the mullet (routine and active metabolism) and swimming performance were tested, using ANCOVA, $(\mathrm{p}<0.05)$ analysis.

\section{RESULTS}

\section{Effect of the time of exposure at LAS-C12 in the routine metabolism}

Tests were performed in which the fishes were acclimated at different concentrations of LAS-C12 and exposure periods. The average variations of the routine metabolism, for each group, as a function of the concentration and time of exposure to LAS-C12, are represented in the table 4.

It was observed that the concentration of $0.5 \mathrm{mgL}^{-1}$ promoted an increase of the oxygen specific consumption for the period of $24 \mathrm{~h}$ (but not necessarily to the control), with subsequent decrease at other exposure periods (48, 72, 96 and $120 \mathrm{~h})$. However there were not significant statistical differences for the routine metabolism between the other periods of time used and the control. Fish exposed for 24, 48, 72, 96 and $120 \mathrm{~h}$ to $1.0 \mathrm{mgL}^{-1}$, presented significant increase of the specific metabolism, compared to its respective controls, for the corresponding periods. At this concentration of LAS-C12, the metabolism tended to increase with the time of exposure, and after 48 $\mathrm{h}$ the increase was statistically significant in relation to the period of $24 \mathrm{~h}$; after $96 \mathrm{~h}$ the consumption of oxygen increased and then it was stabilized. There were statistical differences among the periods of 96,48 and $24 \mathrm{~h}$ of exposure to LAS-C12.

At the concentration of $2.5 \mathrm{mgL}^{-1}$, the specific consumption tended to decrease as a function of time of exposure, and, starting from the period of $24 \mathrm{~h}$, the averages of the consumption were statistically different from the ones obtained for the other periods.

The consumption of oxygen in this concentration of the toxic agent was higher in relation to the control, for 24 and $48 \mathrm{~h}$ of exposure; however, it was smaller than the one or the period of 96 and $120 \mathrm{~h}$. In these cases, a statistically significant difference was not verified between the control and $2.5 \mathrm{mgL}^{-1}$ only for the $72 \mathrm{~h}$ exposure period. 
Table 3 - Specific oxygen consumption $(\mathrm{mlO} / \mathrm{Kg} / \mathrm{min})$ by mullets (routine metabolism), acclimated to the temperatures of the $20^{\circ} \mathrm{C}$ and salinity of 35 , subjected to different LAS-C12 concentrations at different exposure periods. Standard deviation in parenthesis; \% oxygen consumption increase in relation to control. Each value represents the average of 10 determinations.

\begin{tabular}{|c|c|c|c|c|c|c|c|c|}
\hline \multirow{2}{*}{$\begin{array}{l}\text { Time of the } \\
\text { exposure } \\
\text { (in hours) }\end{array}$} & \multicolumn{2}{|c|}{ Control } & \multicolumn{2}{|c|}{$0.5 \mathrm{ppm}$} & \multicolumn{2}{|c|}{$1.0 \mathrm{ppm}$} & \multicolumn{2}{|c|}{$2.5 \mathrm{ppm}$} \\
\hline & $\begin{array}{c}\text { Specific } \\
\text { consumption }\end{array}$ & $\%$ & $\begin{array}{c}\text { Specific } \\
\text { consumption }\end{array}$ & $\%$ & $\begin{array}{c}\text { Specific } \\
\text { consumption }\end{array}$ & $\%$ & $\begin{array}{c}\text { Specific } \\
\text { consumption }\end{array}$ & $\%$ \\
\hline 24 & $1.68(0.07)$ & 100 & $2.13(0.10)$ & 26.8 & $2.23(0.04)^{*}$ & 32.7 & $3.67(0.13)^{*}$ & 118.4 \\
\hline 48 & $1.95(0.12)$ & 100 & $2.02(0.09)$ & 3.5 & $2.91(0.15)^{*}$ & 49.2 & $2.84(0.10)^{*}$ & 45.6 \\
\hline 72 & $1.95(0.03)$ & 100 & $1.95(0.03)$ & 0.0 & $3.00(0.14)^{*}$ & 53.8 & $1.90(0.14)$ & -2.6 \\
\hline 96 & $1.75(0.04)$ & 100 & $1.82(0.07)$ & 4.0 & $3.25(0.08) *$ & 85.7 & $1.04(0.07)^{*}$ & -40.6 \\
\hline 120 & $1.83(0.10)$ & 100 & $1.94(0.04)$ & 6.0 & $3.22(0.06) *$ & 75.9 & $0.62(0.06)^{*}$ & -66.1 \\
\hline
\end{tabular}

During the preliminary tests, concentrations of 5.0 and $10 \mathrm{mgL}^{-1}$ of LAS-C12 were also used. However, in the concentration of $5.0 \mathrm{mgL}^{-1}$ the mullet died after $24 \mathrm{~h}$ of exposure and, in the concentration of $10 \mathrm{mgL}^{-1}$, after just one hour.

\section{Effect of the time of exposure to LAS-C12 in the active metabolism}

The averages of the active metabolism and the time of swimming until fatigue of animals submitted to different exposure periods to each concentration of LAS-C12 are summarized in the Table 4. It can be noticed that fishes exposed to the concentration of $0.5 \mathrm{mgL}^{-1}$ of LAS-C12, during the established periods of time for the experiment, did not present tendency to an increase of the specific metabolism in relation to the control at any of the different exposure periods (Table 4). At the concentration of $1.0 \mathrm{mgL}^{-1}$ of LAS-C12, the metabolism presented a tendency to increase with the time of exposure. The increase was statistically significant in relation o the control for all exposure periods. In $120 \mathrm{~h}$, the consumption of oxygen decreased to values close to the obtained for 24 and $48 \mathrm{~h}$ of exposure. In this concentration there was no statistic differences among the consumption averages obtained in different exposure periods. At the concentration of $2.5 \mathrm{mgL}^{-1}$, the specific consumption presented tendency to decrease starting from $24 \mathrm{~h}$ of exposure.

Table 4 - Specific oxygen consumption (in $\mathrm{mlO} 2 / \mathrm{Kg} / \mathrm{min}$ ) of mullet swimming at the speed of $15 \mathrm{~cm} / \mathrm{seg}$, acclimatized to the salinity of 35 and temperature of $20^{\circ} \mathrm{C}$, as a function of the exposure time and at different concentrations of LAS-C12. Standard deviation in parenthesis, \% consumption in relation to the control. Each value represents the average of 10 determinations.

\begin{tabular}{ccccccccc}
$\begin{array}{c}\text { Time of the } \\
\text { exposure } \\
\text { (in hours) }\end{array}$ & Control & & $\mathbf{0 . 5} \mathbf{~ p p m}$ & & $\mathbf{1 . 0} \mathbf{~ p p m}$ & & $\mathbf{2 . 5} \mathbf{~ p p m}$ \\
\hline & $\begin{array}{c}\text { Specific } \\
\text { consumption }\end{array}$ & $\mathbf{\%}$ & $\begin{array}{c}\text { Specific } \\
\text { consumption }\end{array}$ & $\mathbf{\%}$ & $\begin{array}{c}\text { Specific } \\
\text { consumption }\end{array}$ & $\mathbf{\%}$ & $\begin{array}{c}\text { Specific } \\
\text { consumption }\end{array}$ & $\mathbf{\%}$ \\
\hline 24 & $4.55(0.27)$ & 100 & $4.20(0.16)$ & 92,3 & $5.36(0.46)^{*}$ & 118 & $1.40(0.3)^{*}$ & 30.3 \\
48 & $4.64(0.07)$ & 100 & $4.69(0.7)$ & 101 & $5.30(0.22)^{*}$ & 114 & $1.30(0.14)^{*}$ & 28.8 \\
72 & $4.46(0.17)$ & 100 & $4.10(0.44)$ & 91,9 & $5.55(0.45)^{*}$ & 124 & $0.81(0.08)^{*}$ & 18.1 \\
96 & $4.42(0.25)$ & 100 & $3.76(0.16)^{*}$ & 85 & $5.85(0.42)^{*}$ & 132 & - & - \\
120 & $4.06(0.27)$ & 100 & $4.61(0.11)$ & 114 & $5.24(0.08)^{*}$ & 129 & - & - \\
\hline
\end{tabular}

However, only the averages of the consumption for $72 \mathrm{~h}$ were statistically different from the obtained on the other periods. The consumption of oxygen at this concentration of the toxic agent was smaller in relation to the controls, for 24,48 and
$72 \mathrm{~h}$ of exposure. Significant differences were observed between the data of the controls and the one of $25 \mathrm{mg} . \mathrm{L}^{-1}$, in all the corresponding periods. For the periods of 96 and $120 \mathrm{~h}$ it was not possible to measure the consumption of oxygen, because 
the mullet got tired in less than one minute after being placed in the respirometer.

\section{Effect of the exposure time to LAS-C12 on the time of swimming until exhausted}

In general, the time of swimming until exhausted of the fishes progressively decreased in relation to the control; and considerably decreased at higher concentrations of the toxic agent as well as at longer periods of exposure (Table 5). Table 5, showed that in the control the fishes, on average spent 50.8 to 54 minutes to get tired at the experimental swimming speed of $15 \mathrm{cms}^{-1}$. Comparing the results obtained in the control with the ones obtained in the concentration of $0.5 \mathrm{mgL}^{-}$ ${ }^{1}$, a significant decrease in the time of swimming was observed until exhausted after $96 \mathrm{~h}$ of exposure to LAS-C12, which decreased from 48.2 minutes to 44.4 minutes after $120 \mathrm{~h}$.

At the concentration of $1.0 \mathrm{mgL}^{-1}$, the averages of time of swimming until exhausted showed tendency to decrease at longer periods of exposure, varying from 45 minutes after the exposure of 24 hours, to 33 minutes after the exposure of $96 \mathrm{~h}$. Significant difference was verified between those two averages. At that concentration, significant differences of the averages were detected in relation to the ones of the control in all the periods.

The time of swimming until exhausted of fish submitted to $2.5 \mathrm{mgL}^{-1}$ of LAS-C12 for $24 \mathrm{~h}$ were about 8 minutes. After $72 \mathrm{~h}$ of exposure at this concentration the fish got tired in 3 minutes. Only the average for the period of $72 \mathrm{~h}$ presented significant difference from the ones of the other exposure periods at the same concentration. All the averages obtained for $2.5 \mathrm{mgL}^{-1}$ presented statistically significant differences when compared with the ones of the control.

\section{DISCUSSION}

Several studies have demonstrated an increase of the metabolism of organisms exposed to several toxins (Barbieri et al. 2005). Lemaire et al. (1996), studying the effects of aromatic compositions found a pronounced increase of the consumption of oxygen in fishes exposed to increasing concentration of aromatic compositions. MacLead and Smith (1966) testing the effect of wood fibers in the consumption of oxygen and activity of Pimephales promelas, verified that every duplication in the concentration corresponded to a decrease of $1 \mathrm{mg} / \mathrm{kg} / \mathrm{min}$ in the consumption at an environment with low levels of dissolved oxygen, and of $0.2 \mathrm{mg} / \mathrm{kg} / \mathrm{min}$ at high levels of oxygen. Significant decrease of the swimming capacity using such parameter as indicator of stress was observed.

Table 5 - Variation of the time of swimming until fatigue (in minutes) of mullet, acclimatized at the salinity of 35 and temperature of $20^{\circ} \mathrm{C}$, as a function of different time of exposure (in hours) and at different concentrations of LAS-C12 (in ppm). Between parenthesis - "standard deviation", \% percentage of the consumption in relation to the control. Each value represents the average of 10 determinations.

\begin{tabular}{|c|c|c|c|c|c|c|c|c|}
\hline \multirow{2}{*}{$\begin{array}{l}\text { Time of the } \\
\text { exposure } \\
\text { (in hours) }\end{array}$} & \multicolumn{2}{|c|}{ Control } & \multicolumn{2}{|c|}{$0.5 \mathrm{ppm}$} & \multicolumn{2}{|c|}{$1.0 \mathrm{ppm}$} & \multicolumn{2}{|c|}{$2.5 \mathrm{ppm}$} \\
\hline & $\begin{array}{c}\text { Time } \\
\text { (in minutes) }\end{array}$ & $\%$ & $\begin{array}{c}\text { Time } \\
\text { (in minutes) }\end{array}$ & $\%$ & $\begin{array}{c}\text { Time } \\
\text { (in minutes) }\end{array}$ & $\%$ & $\begin{array}{c}\text { Time } \\
\text { (in minutes) }\end{array}$ & $\%$ \\
\hline 24 & $50.8(2.51)$ & 100 & $47.8(1.39)^{*}$ & 94 & $45(3.50)^{*}$ & 88.5 & $8.0(1.86)^{*}$ & 15.7 \\
\hline 48 & $54.0(1.87)$ & 100 & $47.2(2.51)^{*}$ & 87.4 & $44(3.60)^{*}$ & 81.4 & $5.0(0.96)^{*}$ & 9.2 \\
\hline 72 & $53.4(2.78)$ & 100 & $51.2(2.74)$ & 95.8 & $36(3.70)^{*}$ & 67.4 & $3.0(0.48)^{*}$ & 5.61 \\
\hline 96 & $52.2(2.87)$ & 100 & $48.2(2.63)$ & 92.3 & $33(3.7)^{*}$ & 63.2 & - & - \\
\hline 120 & $53.8(2.57)$ & 100 & $44.4(1.96)^{*}$ & 82.5 & $34(1.8)^{*}$ & 63.1 & - & - \\
\hline
\end{tabular}

In present study a pronounced increase of the routine and active metabolism as the concentration of the LAS-C12 increased. Probably, as it was expected, in the used concentrations, during the short period of experimental time, the effect of the toxin was not enough to damage the metabolic organs in a way to put in risk the absorption of the gas. Apparently that as the gills were involved with the osmorregulation and other metabolic processes, despite the gaseous changes, the detergents, even in low concentrations, harm the good operation of those processes, making the 
individuals exposed to them spend a larger amount of energy in an attempt to maintaining their homeostasis.

Rand (1984) classified a series of fish behaviors that were used as toxicity indicators. Among them, the swimming activity was considered as a good indicator for pollution, even when substances were found at sublethal levels. The time of swimming until exhausted and the consumption of oxygen during the exercise were appropriate to study the acute effects of toxicants in the environment because these parameters provide, fast and easily measurable responses of different species of swimming fishes (Little and Finger, 1990, Kolak, 1999). Studies comparing swimming activity, swimming performance, feeding, escape from predator and duration of the activity of swimming of the rainbow trout demonstrated that those activities were reduced at sublethal exposure to chemical products (Little, et al., 1989).

Toxicants usually affect the swimming activity before the death of the organism. Little et al. (1985), in studies with trout, observed that the swimming performance, feeding, and the behavior of escaping from predators were reduced due to sublethal exposure to Palation and Malathion organophosphates. Also in trouts, the swimming activity was significantly reduced after $96 \mathrm{~h}$ of exposure to a concentration of $5.0 \mathrm{mgL}^{-1}$ of the DEF herbicide (Little et al., 1989). In the case of mullet, as the concentration and the time of exposure to LAS increased, the time of swimming until exhausted was reduced. The animals presented a significant decrease of the swimming capacity after they were submitted for $72 \mathrm{~h}$ to a concentration of $1.0 \mathrm{mgL}^{-1}$ of LAS. A marked reduction of the swimming performance was verified after $72 \mathrm{~h}$ at a concentration of $2.5 \mathrm{mgL}^{-1}$, and the animals got tired after swimming for just 3 minutes.

The present work showed that from the lowest $(0.5$ $\left.\mathrm{mgL}^{-1}\right)$ to the highest $\left(2.5 \mathrm{mgL}^{-1}\right)$ concentration used in experiments that lasted less than two hours, both metabolism and time of swimming until exhausted presented alterations. In the concentration of $2.5 \mathrm{mgL}^{-1}$ the decrease of the capacity of swimming was quite accentuated, making weariness happen up to 4.83 times quicker than in the control. Mullets exposed for $72 \mathrm{~h}$ to the concentration of $2.5 \mathrm{mgL}^{-1}$ practically could not swim at $15 \mathrm{~cm} \cdot \mathrm{s}^{-1}$ anymore. This verification was very disquieting considering that higher concentrations of anionic tensoatives were found in studies performed on the Brazilian coast (Aidar et al., 1997). Besch et al. (1977) demonstrated that the capacity of swimming of carps provides fast indication of the toxicity. In their experiments with DDT up to $0.5 \mathrm{mgL}^{-1}$ it was possible to detect significant alterations in a period of two hours, whereas the $48 \mathrm{~h}$ LC50 was $1.5 \mathrm{mgL}^{-1}$. In trout the swimming performance was altered by Malathion and Fenitrothion in a concentration 33\% below the LC50 (Peterson, 1974). Similar effect was also found for salmon after exposure to copper with concentrations up to $12 \%$ of the necessary one to estimate the LC50 (Walwood and Beamish, 1978). In that way, measurable modifications of swimming could be detected well before mortality. Studies with LAS indicated the reduction of swimming capacity in rainbow trout exposed to $0.2 \mathrm{mgL}^{-1}$ (Hofer, et al., 1994), and in several other species the swimming capacity was affected in concentrations between 0.6 to $4.7 \mathrm{mgL}^{-1}$ (Swedmark et al., 1971, Barbieri et al., 1998).

Alterations in the swimming capacity are reflected in several activities of the organism such as migration, predation or success in escaping from predators, with serious ecological consequences (Reidy et al., 1995, Hymel et al., 2002). Furthermore, the decrease of the time of swimming until exhausted hinders the chances of finding the prey due to the reduction of the search area (Laurence, 1972). This affects the feeding efficiency leading to a concomitant decrease in the amount of available energy for growth (Little and Finger, 1990)

The swimming physiology of a fish is affected by the maturity and organic conditions, degree if exposure to other stress factors, acclimation, time of test and physical and chemical parameters, such as temperature, salinity, water quality, light, size or shape of the fishbowls (Little and Finger,1990). Therefore, tests involving behavior responses require a rigid and controlled standardization of the methodology, with a rigorous uniformization of the experimental procedures as well as handling of the test organisms.

If the results obtained here presented for mullet under an ecological perspective, the first response of the fish could be trying to escape, and, in the case of an environment totally polluted we could maybe find a similar response in sealed respirometers where we performed the experiments.

The study of swimming capacity carried out for different species of fish provides inputs towards 
the understanding of the ecological role of the species in their environment since it evaluated the escape capacity from a predator (Kasapi et al., 1992), the effects of swimming activity under growth (Hammer and Schwarzl, 1996), the corporal composition and the caloric content (Reidy et al., 1995), the relationship between swimming and consumption of oxygen (Barbieri et al., 1998, 2000 and 2002), the relationship between the shape of the caudal fin and swimming speed developed by the fish (Karposian et al., 1990), the ability and the swimming speed as a factor for the occupation of several environments within a same area (Peake et al., 1997).

The swimming performance is a valid parameter and a consistent index of the subletal toxicity that can easily be incorporated into the test protocols to increase the sensitivity of the pattern of the toxicity test (Wicks, et al., 2002). The time of swimming until exhausted can strictly be monitored in laboratory with simple equipments that can be easily adapted for use in toxicity tests in the field. The reduction of the time of swimming until exhausted can be a result of changes in the distribution of energy that the fish should allocate for the maintenance of its homeostasis (Kerr, 1971), so the fish stops spending energy with swimming and redirects it to operate vital organs for its survival.

The activity of a toxicant depends on its concentration and time of exposure of the organism to the pollutant (Fellenberg, 1980). An amount of toxicant substance generally acts, for example, in a $10 \mathrm{Kg}$ fish with the double of the intensity observed in a $20 \mathrm{Kg}$ fish (Fellenberg, 1980). For that reason, the maximum permissible doses of a toxicant substance are not indicated as absolute amounts, but always in relation to the individual's weight and the time of exposure. Therefore, the longer the time of exposure of the organism to the pollutant the worse the effects on the organism.

In the present study, the sublethal exposure of mullets to the detergent increased the rate of the routine metabolism in low concentrations of LASC12 (1.0 $\left.\mathrm{mgL}^{-1}\right)$. Nevertheless, when increasing the concentration a depression in the metabolism occurred. The largest metabolic decrease was evidenced when mullets were exposed to a concentration of $2.5 \mathrm{mgL}^{-1}$ for $120 \mathrm{~h}$. A similar fact happened in fish swimming at $15 \mathrm{~cm} \cdot \mathrm{s}^{-1}$ exposed to LAS-C12 during a period of $24 \mathrm{~h}$. There was an increase of the active metabolism at the concentration of $1.0 \mathrm{mgL}^{-1}$ and a decrease of the same at the concentration of $2.5 \mathrm{mgL}^{-1}$ after $120 \mathrm{~h}$ of exposure. The time of swimming until fatigue decreased from 50.8 to 8 minutes, representing a decrease of $84.25 \%$ of the swimming capacity of the mullet. The sublethal pollution generally decreased the capacity of the fish to move or to swim, directly influencing the time of swimming until fatigue. For the mullets, with the increase in the exposure period and concentration of LAS-C12, the degree of damage of the organs and tissues probably caused progressive decrease of the metabolic rates until death, in the case of fish exposed to $5.0 \mathrm{mgL}^{-1}$ of LAS.

The results obtained indicated that the metabolic rate of mullets increased about $86.2 \%$ after exposure for $96 \mathrm{~h}$ to LAS at a concentration of 1.0 $\mathrm{mgL}^{-1}$ and decreased $66.13 \%$ for mullet exposed to $120 \mathrm{~h}$ at the concentration of $2.5 \mathrm{mgL}^{-1}$. The significant increase in the consumption of oxygen should probably be, as one of its factors, due to problems caused by alterations of the energy metabolism. Following that initial increase in oxygen consumption, at longer exposure or at higher concentrations, a reduction of the metabolism, occurred like what happened in the concentration of $2.5 \mathrm{mgL}^{-1}$ for $120 \mathrm{~h}$ of exposure. Some studies of the pathological effects caused by chronic exposure to synthetic detergents evidenced the gradual destruction of the gills filaments, killing the fishes due to asphyxia (Misra et al., 1985; Zaccone et al., 1985 a; Huang and Wang, 1995), which was what probably happened in this study with mullets exposed to $5.0 \mathrm{mgL}^{-1}$ of LAS$\mathrm{C} 12$, for about $24 \mathrm{~h}$, and to $10 \mathrm{mgL}^{-1}$, that died in less than one hour.

The effect of LAS in the metabolic enzymatic activity in gills of Heteropneustes fossilis indicated that this toxin had a high potential to interfere with the aerobic mechanisms (Zaccone et al., 1985a). For mullet as the concentration of LAS increased from 0.5 to $2.5 \mathrm{mgL}^{-1}$ both active and routine metabolism also rose, besides decreasing the time of swimming until exhausted. Ribelles et al. (1995), studying the fish Sparus aurata, found pronounced alteration in the branchial filaments of individuals exposed to concentrations from 3 to 15 $\mathrm{mgL}^{-1}$ of SDS and LAS. The lamella`s epithelial tissue got three times more swollen than normal due to edemas. Also, thickening of cellular walls was observed. Supriyono et al. (1998) verified in the shrimp Panaeus japonicus exposed to 0.75 
$\mathrm{mgL}^{-1}$ of LAS-C12 for $96 \mathrm{~h}$, that the secondary filaments of the gills were fused due to necrosis of the cells.

In general, when an extensive destruction of the metabolic surface of the gills occurs, there was a decrease of the entrance of oxygen in bloodstream of the fishes, causing suffocation (Abel, 1974; Ribelles et al., 1995). In this case, the fish would decrease the tolerance to low concentrations of dissolved oxygen (Wang and Huang, 1994). The swelling process would inhibit the passage of oxygen from the water to the bloodstream of the fish, causing it to consume less oxygen (Huang and Wang, 1994). For mullets exposed for a period of until $120 \mathrm{~h}$ to LAS-C12, a smaller specific consumption of oxygen was observed when compared to the control. Such fact could be related to the swelling of the gills that would be hindering the passage of oxygen. However, for short periods of exposure to the polluting agent, a maximum of one and a half hour, an increase was observed in the specific consumption of oxygen. In this case it was very likely that the period was not enough to damage the gills.

\section{RESUMO}

Este trabalho investiga os efeitos toxicológicos do LAS-C12 em diferentes concentrações $\left(0,0 \mathrm{mgL}^{-1}\right.$, $0,5 \mathrm{mgL}^{-1}, 1 \mathrm{mgL}^{-1}$ and $\left.2,5 \mathrm{mgL}^{-1}\right)$ e em diferentes tempos de exposições (24, 48, 72, 96 e 120horas) sobre Mugil platanus (tainha), utilizando o metabolismo de rotina, ativo e o tempo de natação até o cansaço. Peixes expostos a $1,0 \mathrm{mgL}^{-1}$ por 24 , $48,72,96$ e 120 horas apresentaram um aumento significante no metabolismo de rotina. $\mathrm{Na}$ concentração de $2,5 \mathrm{mgL}^{-1} \mathrm{o}$ metabolismo ativo diminuiu após 48 horas de exposição. Entretanto só após 72 horas houve diferença estatística. Não foi possível medir o consumo de oxigênio nos períodos de exposições de 96 e 120 horas por que os peixes cansavam-se após um minuto do respirômetro ser ligado. O tempo de natação até o cansaço de peixes expostos a $2,5 \mathrm{mgL}^{-1}$ após 24 horas foi de 8 minutos. Após 72 horas de exposição foi de 3 minutos.

\section{REFERENCES}

Abel, P. D. (1974), Toxicity of synthetic detergent to fish and aquatic invertebrates. J. Fish Biol., 6, 279-298.

Aidar, E., Sigaud-Kutner T. C. S., Nishihara, L., Schinke, K. P., Braga, M. C. C., Farah, R. E. and Kutner, M. B. B. (1997), Marine phytoplankton assays: effects of detergents. Mar. Environ. Res., 41 : (4), 1-14.

Barbieri, E., Phan, V. N., Gomes, V. (1998), Efeito do DSS, dodecil sulfato de sódio, no metabolismo e na capacidade de natação de Cyprinus carpio. Rev. Brasil. Biol. 58 (2): 263-271.

Barbieri, E., Phan, V. N., Gomes, V. (2000), Effects of LAS-C12, Linear Alkybenzene Sulphonate, on Metabolic rate and Swimming Capacity of Cyprinus carpio. Ecotox. Environ. Rest. 3(2)60-75.

Barbieri, E., Oliveira, I.R., Serralheiro, P. (2002), The use of metabolism to evaluate the toxicity of dodecy benzen sodium sulfonate on the Mugil platanus. J. Exp. Mar. Bio. Ecol. 277: 109-127.

Barbieri, E., Passos, E. A., Garcia, C. A B. (2005), Use of metabolism to evaluate the sublethal toxicity of mercury on Farfantepaneus brasiliensis larvae (Latreille 1817, crustacean. J. Shell. Res. 24 (4): 1229-1235.

Beamish, F. W. H. (1978), In: Hoar, W. S., Randall, D. J. (Eds), Swimming Capacity. In Fish Physiology, vol. 7 Academic Press, London, pp. 101-187.

Besch, W. K., Kemball, A. K., Meyer-Warden, E., Scharf, B. (1977), A biological monitoring system employing rheotaxis of fish,. In: Cairns Jr., K.L. Dickson and G. F. Westlake (ed.), Biological Monitoring of Water and Effluent Quality. American Society for Testing and Materials, Philadelphia, PA. 56-74pp.

Boudou, A. and Ribeyre, F. (1989), Fish as "biological model" for experimental studies in ecotoxicology. In: A. Boudou and F. Riibeyre (eds.), Aquatic Ecotoxicology Fundamental Concepts and Methodologies. vol. VIII. CRC Press Inc. Florida. 127-150pp.

Brett, J. R. and Groves, T. D. (1979), Physiological energetics. In: Hoar, W. S., Randall D. J. and Brett, J. R. Eds. Fish Physiology. New York, Academic Press. vol. 8: 279-352.

Carvalho, P. M. S. (1992), Bioenergética do camarão sete-barbas. Dissertação de mestrado. Instituto Oceanográfico-Universidade de São Paulo. 206p.

Christiansen, P. D., Brozek, K., Hansen, B. W. (1998), Energetic and behavioral responses by the common goby, Pomatoschistus microps (Kroyer), exposed to linear alkybenzene sulfonate. Environ. Toxicol. Chem. 17(10): 2051-2057. 
Cleveland, L., Little, E. E., Hamilton, S. J., Buckler, D. R., Hunn, J. B. (1986), Interactive toxicity of aluminum and acidity to early life stages of brook trout. Trans. Am. Fish. Soc. 115: 610-620.

Dodson, J. J. and Mayfield, C. I. (1979), Modification of the rheotropic response of rainbow trout (Salmo gairdneri) by subletal doses of the aquatic herbicides diquat and simazine. Environ. Pollut. 18: 147-157.

Fellenberg, G. (1980), Introdução aos problemas da poluição ambiental. Editora da Universidade de São Paulo, São Paulo, Brasil. 120p.

Fry, F. E. J. (1971), The effect of environmental factors on the physiology of fish. In Hoar, W. S. and Randall, D. J. eds. Fish Physiology. New York, Academic Press. vol.6: 1-98.

Grippo, M. A. and Heath, A. G. (2003). The effect of mercury on the feeding behavior of fathead minnows. Ecotox. Environ. Saf. 55: 187-198.

Hammer, C. and Schwarz, G. (1996), The effect prolonged swimming activity on the growth proximate body composition and calorific content of O-age group whiting (Merlangius merlangus L., Gadidae). Arch. Fish. Mar. Res. 44 (1/2): 13-32.

Hodson, P. V.(1988), The effect of metal metabolism on uptake, deposition and toxicity in fish. In D. C. Malins and A. Jesen (eds.), Aquatic Toxicology. Toxic Chemicals and Aquatic Life: Research and management. Elsevier Science Publishers B. V., Amsterdam 11:. 3-18.

Hofer, R., Jeney, Z., Bucher, F. (1994), Chronic effects of linear alkylbenzene sulfonate (LAS) and ammonia on rainbow-trout (Oncorhynchus mykiss) fry. Wat. Crit. Lim. 29 (12): 2725-2729.

Howard, T. E. (1975), Swimming performance of juvenile coho salmon (Oncorhynchus kisutch) exposed to bleached kraft pulpmill effuent. J. Fish. Res. Bd Can. 32: 789-793.

Huang, B. Q. and Wang, D. Y. (1994), Effects of linear alkybenzene sulfonate (LAS) on the respiratory functions of tigerperch (Terapon-jurbua). Zoo. Stud. 33 (3): 205-210.

Huang, B. Q. and Wang, D. Y. (1995). Corneal damage in young tigerperch (Terapon jarbua) exposed to the surfactant linear alkylbenzene sulfonate (LAS). Zoo. Stu. 34 (1): 41-46.

Hymel, M. K., Baltz, D. M., Chesney, E. J., Tarr, M. A., Kolok, A . S. (2002), Swimming performance of juvenile Florida Pompano Exposed to Ethylene Glycol. Trans. Am. Fish. Soc. 131: 1152-1163.

Kasapi, W. A., Domenici, P. Blake, R. W., Harper, D. (1992), The kinematics and performance of escape responses of knifefish Xenomystys nigri. Can. J. Zool. 71: 189-195.

Kerr, S. R. (1971), Analysis of laboratory experiments on growth efficiency of fish. J. Fish. Res. Bd. Canada 28: 801-808.
Kloth, T. C. and Wohlschiag, D. E. (1972), Size-related metabolic responses of the pinfish, Lagodon rhomboides, to salinity variations and sublethal petrochemical pollution. Mar. Sci. 16: 125-137.

Kolak, A S. (1999), Interindividual variation in the prolonged locomotor performance of ectothermic vertebrates: a comparison of fish and herpetofaunal methodologies and a brief review of the recent fish literature. Can. J. Fish Aqua. Sci. 56: 708-710.

Laurence, G. C. (1972), Comparative swimming abilities of fed and starved larval largemouth bass (Micropterus salmonides). J. Fish Biol. 4: 73-78.

Lemaire, P., Sturve, J. Forlin, L., Livingstone, D. R. (1996), Studies on aromatic hydrocarbon quinone metabolism and DT-diaphorase function in liver of fish species. Mar. Environ. Res. 2 (1-4): 317-321.

Little, E. E., Flerov, B. A., Ruzhinskaya, M. N. (1985), Behavioral approaches in aquatic toxicity: A review. In: Mehrle, P. M. Jr., Gray, R. H. and Kendall, R. L. (eds.), Toxic Substances in the Aquatic Environment: An International Aspect. American Fisheries Society, Water Quality Section, Bethesda, MD. 72-98pp.

Little, E. E., Archeski, R. D., Flerox, B. A., Kozlovskaya, V. I. (1989), Behavioral indicators of sublethal toxicity in rainbow trout. Arch. Environ. Contam. Toxicol. 12: 43 -56.

Little, E. E., Finger, S. E. (1990), Swimming behavior as an indicator of sublethal toxicity in fish. Environm. Toxicol. and Chemistry 9: 13-19.

MaClead, J.C., Jr. Smith, L. L. (1966), Effects of pulpwood fiber on oxygen consumption. Ph.D. Thesis, University of London. 126p.

Miller, D. C. (1980), Some applications of locomotor response in pollution effects. Rapp. P. V. Reun. Cons. Int. Explor. Mer. 179: 154-161.

Misra, V., Lal, H., Chawla, G., Viswanathan, P. N. (1985), Pathomorphological changes in gills of fish fingerlings (Cirrhina mrigala) by linear alky benzene sulfonate. Ecotoxicol. Environ. Saf. 10: 302-308.

Moore, W. J. (1976), Físico-Química, EDUSP, São Paulo, 567p.

Peake, S., Mckinley, R. S., Scruton, D. A.(1997), Swimming performance of various freshwater Newfoundland salmonids relative to habitat selection and fishway design. J. Fish Biol.51:710-723.

Peterson, R. H. (1974), Influence of fenitrothion on swimming velocities of brook trout (Salvelinus fontinalis). J. Fish. Res. Bd Can. 31: 1757-1762.

Rand, G. M. (1977), The effects of exposure to a subacute concentration of parathion on the general locomotor behavior of the goldfish. Bull. Environ. Contam. Toxicol. 18: 259-266.

Rand, G. M. (1984), The use of behavioral measurements to assess toxicant induced stress in marine organisms. In G. Persoone, E. Jaspers and C. Claus, (Eds.), Ecotoxicological testing for the marine environment, vol.2. Institute for Marine Scientific Research, Bredene, Belgium,pp.431-456. 
Reidy, S. P., Nelson, J. A., Tang, Y., Kerr. S. R. (1995), Post-exercise metabolic rate in Atlantic cod and its dependence upon the method of exhaustion. J. Fish Biol. 47: 377-386.

Ribelles, A., Carrasco, C., Rosety, M. (1995), Morphological and histochemical-changes caused by sodium dodecil-sulfate in the Sparus aurata, L. Euro. J. Histochem. 39: (2) 141-148.

Schreck, C. B. (1990), Physiological, behavioral and performance indicators of stress. Am. Fish. Soc. Symposium. 8: 29-37.

Silveira, M. A., Pereira, V. N., Tommasi, L. R. (1982), Resultados preliminares sobre os teores de detergentes aniônicos na Baía e Estuário de Santos. Bolm Inst. oceanogr. S Paulo. 31 (2): 95-99.

Smith, R. L. e Hargreves, B. R. (1984), Oxygen consumption in Neomysis americana (Crustacea: Mysidacea), and the effects of naphthalene exposure. Mar. Biol. 79: 109-116

Supriyono, E., Takashima, F., Strussmann, C. A. (1998), Toxicity of Linear alkylbenzene sulphonate (LAS) to juvenile kuruma shrimp, $P$. japonicus: a histopathological study on acute and sub-chronic levels. J. Tokyo Univ. Fish. 85(1):1-10.

Swedmark, M., Braaten, B., Emanuelsson, E., Granmo, A. (1971), Biological effects of surface active agents on marine animals. Mar. Biol. 9: 183-201.

Walwood, K. G. e Beamish, F. W. H. (1978), The effects of copper, $\mathrm{pH}$, and hardness on the critical swimming performance of rainbow trout, Salmo gairdeneri, Water Res. 12: 611-619.
Wang, D. Y. and Huang, B. Q. (1994), Effects of LAS on the membrane potencial of gill epithelium in young tigerperch (Terapon jarbua). Zoo. Studies 33 (2): 170-173.

Wang, D. Y. and Huang, B. Q. (1995), Hematological effects of detergents LAS toxicity in young thornfish, Terapon jarbua. J. Fish. Soc. of Taiwan. 22 (2): 163168.

Zaccone, G., Fasulo, S., Lo Cascio, P., Licata, A. (1985a), Patterns of enzymes activities in the gills of the catfish, Heteropneus fossilis exposed to anionactive detergent Na-Alkybenzene sulphonate (LAS). Histochem. Jour. 82: 341-343.

Wicks, B. J., Joensen, R., Tang, Q., Randall, D. J. (2002), Swimming and ammonia toxicity in salmonids: the effects of sub lethal ammonia exposure on the swimming performance of coho salmon and the acute toxicity of ammonia in swimming and resting rainbow trout. Aquat. Toxicol. 59: 55-69.

Received: July 05, 2005; Revised: October 20, 2005; Accepted: September 18, 2006. 